\title{
Cells Tissues Organs
}

\section{in vivo, in vitro}

Founded 1945 as 'Acta Anatomica' by R. Chambers, G. Glimstedt, T. Peterfi and G. Wolf-Heidegger Continued $1962-1974$ by E.A. Boyden, $1955-1980$ by A. Delmas, $1972-1980$ by F. Walberg, $1945-1980$ by G. Wolf-Heidegger, 1981-1988 by R. O’Rahilly, Davis, Calif., $1989-1990$ by G.E. Goslow, Jr., Providence, R.I., 1981-1992 by W. Lierse, Hamburg, since 1992 by H.-W. Denker, Essen, and A.W. English, Atlanta, Ga., continued 1999 as 'Cells Tissues Organs' by H.-W. Denker, Essen, and A.W. English, Atlanta, Ga.

\section{Editors-in-Chief}

H.-W. Denker, Essen

A.W. English, Atlanta, Ga.

\section{Associate Editors}

Developmental Biology

K.K. Hirschi, Houston, Tex.

E-Mail: khirschi@bcm.edu

D. Newgreen, Melbourne

E-Mail: don.newgreen@mcri.edu.au

C. Viebahn, Göttingen

E-Mail: cviebah@gwdg.de

Stem Cells and Tissue Engineering

S.F. Badylak, Pittsburgh, Pa.

E-Mail: badylaks@msx.upmc.edu

U. Just, Kiel

E-Mail: ujust@biochem.uni-kiel.de

L.E. Niklason, New Haven, Conn.

E-Mail: laura.niklason@yale.edu

A. Ratcliffe, San Diego, Calif.

E-Mail: anthonyratcliffe@synthasome.com

A.M. Wobus, Gatersleben

E-Mail: wobusam@ipk-gatersleben.de
Tumor Cell Plasticity

E. Thompson, Melbourne

E-Mail: rik@medstv.unimelb.edu.au

\section{Neurosciences}

R. Bellamkonda, Atlanta, Ga. E-Mail: ravi@bme.gatech.edu

M. Frotscher, Freiburg i.Br.

E-Mail: frotsch@sun2.ruf.uni-freiburg.de

W.L. Neuhuber, Erlangen

E-Mail: winfried.neuhuber@rzmail.uni-erlangen.de

M. Shoichet, Toronto

E-Mail: molly.shoichet@utoronto.ca

Functional Anatomy and

Biomechanics

L. Gallo, Zürich

E-Mail: luigi@zui.unizh.ch

F. Eckstein, Salzburg

E-Mail: felix.eckstein@pmu.ac.at

\section{Editorial Board}

A. Bader, Leipzig

F. Beck, Leicester

A.L. Boskey, New York, N.Y.

R.C. Burghardt, College Station, Tex.

C. Farnum, Ithaca, N.Y.

R.H.W. Funk, Dresden

N.E. Fusenig, Heidelberg

J.W. Hermanson, Ithaca, N.Y.
C.J. Kirkpatrick, Mainz
P. Köpf-Maier, Berlin
W. Kummer, Giessen
K.G. Marra, Pittsburgh, Pa.
A. Müller, Würzburg
O. Ohtani, Toyama
P.J. Reier, Gainesville, Fla.
R. Roy, Los Angeles, Calif.

R. Segal, Chapel Hill, N.C.

F. Sinowatz, Munich

M. Sittinger, Berlin

T. Skutella, Tübingen

G.B. Stark, Freiburg i.Br.

C.G. Widmer, Gainesville, Fla. 
S. Karger

Medical and Scientific Publishers

Basel $•$ Freiburg $\bullet$ Paris $\cdot$ London $\cdot$ New York

New Delhi $\bullet$ Bangkok $\bullet$ Beijing $\bullet$ Tokyo

Kuala Lumpur $\cdot$ Singapore $\cdot$ Sydney
Disclaimer

The statements, opinions and data contained in this publication are solely those of the individual authors and contributors and not of the publisher and the editor(s). The appearance of advertisements in the journal is not a warranty, endorsement or approval of the products or services advertised or of their effectiveness, quality or safety. The publisher and the editor(s) disclaim responsibility for any injury to persons or property resulting from any ideas, methods, instructions or products referred to in the content or advertisements.

Drug Dosage

The authors and the publisher have exerted every effort to ensure that drug selection and dosage set forth in this text are in accord with current recommendations and practice at the time of publication. However, in view of ongoing research, changes in government regulations, and the constant flow of information relating to drug therapy and drug reactions, the reader is urged to check the package insert for each drug for any change in indications and dosage and for added warnings and precautions. This is particularly important when the recommended agent is a new and/or infrequently employed drug.
All rights reserved.

No part of this publication may be translated into other languages, reproduced or utilized in any form or by any means, electronic or mechanical, including photocopying, recording, microcopying, or by any information storage and retrieval system, without permission in writing from the publisher or, in the case of photocopying, direct payment of a specified fee to the Copyright Clearance Center (see 'General Information')

(c) Copyright 2011 by S. Karger AG

P.O. Box, CH-4009 Basel (Switzerland)

Printed in Switzerland

on acid-free and non-aging paper (ISO 9706) by

Reinhardt Druck, Basel

\section{KARGER}


No. 1

Original Papers

1 BMP-2 and TGF $\beta 2$ Shared Pathways Regulate Endocardial Cell Transformation

Townsend, T.A.; Robinson, J.Y.; Deig, C.R.; Hill, C.R.; Misfeldt, A.

(Nashville, Tenn.); Blobe, G.C. (Durham, N.C.); Barnett, J.V.

(Nashville, Tenn.)

13 Engineered Vascular Tissue Fabricated from Aggregated Smooth Muscle Cells

Gwyther, T.A.; Hu, J.Z.; Christakis, A.G.; Skorinko, J.K.; Shaw, S.M.; Billiar, K.L.; Rolle, M.W. (Worcester, Mass.)

25 Diminished Type III Collagen Promotes Myofibroblast Differentiation and Increases Scar Deposition in Cutaneous Wound Healing

Volk, S.W.; Wang, Y.; Mauldin, E.A. (Philadelphia, Pa.); Liechty, K.W. (Jackson, Miss.); Adams, S.L. (Philadelphia, Pa.)

38 Sox9 Expression during Fracture Repair Shintaku, Y. (Suita); Murakami, T.; Yanagita, T.; Kawanabe, N. (Okayama); Fukunaga, T.; Matsuzaki, K. (Sendai); Uematsu, S.; Yoshida, Y.; Kamioka, H. (Okayama); Takano-Yamamoto, T. (Sendai); Takada, K. (Suita); Yamashiro, T. (Okayama)

49 DLX3 Homeodomain Mutations Cause Tricho-Dento-Osseous Syndrome with Novel Phenotypes

Nieminen, P.; Lukinmaa, P.-L.; Alapulli, H. (Helsinki); Methuen, M.

(Kuopio); Suojärvi, T.; Kivirikko, S.; Peltola, J.; Asikainen, M.; Alaluusua, S. (Helsinki)

60 Hypomaturation Amelogenesis Imperfecta due to WDR72 Mutations: A Novel Mutation and Ultrastructural Analyses of Deciduous Teeth

El-Sayed, W.; Shore, R.C.; Parry, D.A.; Inglehearn, C.F.; Mighell, A.J. (Leeds)

67 Thymulin Gene Therapy Prevents the Histomorphometric Changes Induced by Thymulin Deficiency in the Thyrotrope Population of Mice

Martines, E.V. (La Plata/Libertador San Martín); Reggiani, P.C.;

Schwerdt, J.I.; Goya, R.G.; Cónsole, G.M. (La Plata)

Hypotheses and Concepts

76 A New Possible Function for Placental Pericytes

Jones, C.J.P. (Manchester); Desoye, G. (Graz)
No. 2-4

Advances in the Chemistry and Biology of Mineralized Tissues Guest Editors: Goldberg, H.A. (London, Ont.); MacDougall, M.

(Birmingham, Ala.); Moradian-Oldak, J. (Los Angeles, Calif.)

90 Preface

Goldberg, H.A. (London, Ont.); MacDougall, M.B. (Birmingham, Ala.); Moradian-Oldak, J. (Los Angeles, Calif.)

92 Crystallization Pathways in Bone Mahamid, J.; Addadi, L.; Weiner, S. (Rehovot)

98 Evolutionary Origins of Animal Skeletal Biomineralization Murdock, D.J.E.; Donoghue, P.C.J. (Bristol)

103 Ultrastructure of the Mantle of the Gastropod Haliotis asinina and Mechanisms of Shell Regionalization

McDougall, C.; Green, K.; Jackson, D.J.; Degnan, B.M. (Brisbane, Qld.)

108 The SCPP Gene Family and the Complexity of Hard Tissues in Vertebrates

Kawasaki, K. (Pennsylvania, Pa.)

113 DMP1 and DSPP: Evidence for Duplication and Convergent Evolution of Two SIBLING Proteins Fisher, L.W. (Bethesda, Md.)

119 Poorly Ordered Bone as an Endogenous Scaffold for the Deposition of Highly Oriented Lamellar Tissue in Rapidly Growing Ovine Bone

Kerschnitzki, M. (Potsdam/Berlin); Wagermaier, W.; Liu, Y. (Potsdam); Roschger, P. (Vienna); Duda, G.N. (Berlin); Fratzl, P. (Potsdam/Vienna/ Berlin)

124 Enamel-Calibrated Lamellar Bone Reveals Long Period Growth Rate Variability in Humans

Bromage, T.G. (New York, N.Y.); Juwayeyi, Y.M. (Brooklyn, N.Y.); Smolyar, I (Silver Spring, Md.); Hu, B. (New York, N.Y.); Gomez, S. (Cadiz); Chisi, J. (Blantyre)

131 On the Formation and Functions of High and Very High Magnesium Calcites in the Continuously Growing Teeth of the Echinoderm Lytechinus variegatus: Development of Crystallinity and Protein Involvement Veis, A.; Stock, S.R.; Alvares, K.; Lux, E. (Chicago, Ill.)

\section{KARGER}

Fax +41613061234 E-Mail karger@karger.ch www.karger.com

\section{2011 S. Karger AG, Basel}

Access to full text and tables of contents, including tentative ones for forthcoming issues: www.karger.com/cto_issues 
138 Eliminating Exposure to Aqueous Solvents Is Necessary for the Early Detection and Ultrastructural Elemental Analysis of Sites of Calcium and Phosphorus Enrichment in Mineralizing UMR106-01 Osteoblastic Cultures

Studer, D.; Hillmann-Marti, T. (Bern); Huffman, N.T.; Gorski, J.P. (Kansas City, Mo.)

146 Epigenetic Regulation of Early Osteogenesis and Mineralized Tissue Formation by a HOXA 10-PBX1-Associated Complex Gordon, J.A.R.; Hassan, M.Q. (Worcester, Mass.); Koss, M. (New York, N.Y.); Montecino, M. (Santiago); Selleri, L. (New York, N.Y.); van Wijnen, A.J.; Stein, J.L.; Stein, G.S.; Lian, J.B. (Worcester, Mass.)

151 Transcriptional Regulation of Msx1 Natural Antisense Transcript

Babajko, S.; Méary, F.; Petit, S.; Fernandes, I.; Berdal, A. (Paris)

156 Regulation of Bmp4 Expression in Odontogenic Mesenchyme: From Simple to Complex

Kong, H. (Dallas, Tex.); Wang, Y. (Buffalo, N.Y.); Patel, M.; Mues, G.; D'Souza, R.N. (Dallas, Tex.)

161 Chondrocyte-Specific Regulatory Activity of Runx2 Is Essential for Survival and Skeletal Development Chen, H.; Ghori-Javed, F.Y.; Rashid, H.; Serra, R. (Birmingham, Ala.); Gutierrez, S.E. (Concepción); Javed, A. (Birmingham, Ala.)

166 Cryogenic Transmission Electron Microscopy Study of Amelogenin Self-Assembly at Different $\mathbf{p H}$ Fang, P.-A. (Pittsburgh, Pa.); Margolis, H.C. (Cambridge, Ma.); Conway, J.F (Pittsburgh, Pa.); Simmer, J.P. (Ann Arbor, Mich.); Dickinson, G.H.; Beniash, E. (Pittsburgh, Pa.)

171 Polyphosphates Affect Biological Apatite Nucleation Omelon, S. (Ottawa, Ont.); Grynpas, M. (Toronto, Ont.)

176 Citrate Modulates Calcium Oxalate Crystal Growth by Face-Specific Interactions

Grohe, B.; O’Young, J.; Langdon, A.; Karttunen, M.; Goldberg, H.A.; Hunter, G.K. (London, Ont.)

182 Theoretical Study of Bone Sialoprotein in Bone Biomineralization

Yang, Y. (Madison, Wisc.); Mkhonto, D. (Brumeria); Cui, Q.; Sahai, N. (Madison, Wisc.)

188 Potential Role of the Amelogenin N-Terminus in the Regulation of Calcium Phosphate Formation in vitro Le Norcy, E.; Kwak, S.-Y.; Wiedemann-Bidlack, F.B. (Cambridge, Mass.); Beniash, E. (Pittsburgh, Pa.); Yamakoshi, Y.; Simmer, J.P. (Ann Arbor, Mich.); Margolis, H.C. (Cambridge, Mass.)

194 The Cooperation of Enamelin and Amelogenin in Controlling Octacalcium Phosphate Crystal Morphology

Fan, D. (Los Angeles, Calif.); Iijima, M. (Gifu); Bromley, K.M.; Yang, X.; Mathew, S.; Moradian-Oldak, J. (Los Angeles, Calif.)

199 Roles of DMP1 Processing in Osteogenesis, Dentinogenesis and Chondrogenesis

Sun, Y. (Dallas, Tex./Harbin); Chen, L.; Ma, S.; Zhou, J. (Harbin); Zhang, H.; Feng, J.Q.; Qin, C. (Dallas, Tex.)

205 Differential Effects of Fibromodulin Deficiency on Mouse Mandibular Bones and Teeth: A Micro-CT Time Course Study Goldberg, M.; Marchadier, A.; Vidal, C.; Harichane, Y.; Kamoun-Goldrat, A.; Kellermann, O. (Paris); Kilts, T.; Young, M. (Bethesda, Md.)

211 Why Does Enamel in Klk4-Null Mice Break above the Dentino-Enamel Junction?

Simmer, J.P.; Hu, Y.; Richardson, A.S. (Ann Arbor, Mich.); Bartlett, J.D. (Cambridge, Mass.); Hu, J.C.-C. (Ann Arbor, Mich.)

216 Abnormalities in the Enamel in Bmp2-Deficient Mice Feng, J. (San Antonio, Tex./Fuzhou); Yang, G.; Yuan, G. (Wuhan); Gluhak-Heinrich, J.; Yang, W.; Wang, L. (San Antonio, Tex.); Chen, Z. (Wuhan); Schulze McDaniel, J.; Donly, K.J.; Harris, S.E. (San Antonio, Tex.); MacDougall, M. (Birmingham, Ala.); Chen, S. (San Antonio, Tex.)

222 MMP20 Cleaves E-Cadherin and Influences Ameloblast Development

Bartlett, J.D. (Cambridge, Mass.); Yamakoshi, Y.; Simmer, J.P. (Ann Arbor, Mich.); Nanci, A. (Montreal, Que.); Smith, C.E. (Ann Arbor, Mich./Montreal, Que.)
227 Dental Enamel Structure Is Altered by Expression of Dominant Negative RhoA in Ameloblasts

Li, Y.; Pugach, M.K.; Kuehl, M.A.; Peng, L.; Bouchard, J.; Hwang, S.Y.; Gibson, C.W. (Philadelphia, Pa.)

232 Runx2 Regulates the Gene Network Associated with Insulin Signaling and Energy Homeostasis

Adhami, M.; Ghori-Javed, F.Y.; Chen, H. (Birmingham, Ala.); Gutierrez, S.E. (Concepción); Javed, A. (Birmingham, Ala.)

238 Osteoclasts in the Dental Microenvironment: A Delicate Balance Controls Dental Histogenesis Berdal, A. (Paris); Castaneda, B. (Paris/Medellin); Aïoub, M.; Néfussi, J.R. (Paris); Mueller, C. (Strasbourg); Descroix, V. (Paris); Lézot, F. (Paris/Nantes)

244 Comprehensive Skeletal Phenotyping and Linkage Mapping in an Intercross of Recombinant Congenic Mouse Strains HCB-8 and HCB-23

Saless, N.; Litscher, S.J.; Houlihan, M.J.; Han, I.K. (Madison, Wisc.); Wilson, D. (Madison, Wisc./Fort Valley, Ga.); Demant, P. (Buffalo, N.Y.); Blank, R.D. (Madison, Wisc.)

249 Enamel Pathology Resulting from Loss of Function in the Cystic Fibrosis Transmembrane Conductance Regulator in a Porcine Animal Model

Chang, E.H. (Iowa City, Iowa); Lacruz, R.S. (Los Angeles, Calif.); Bromage, T.G. (New York, N.Y.); Bringas, P., Jr. (Los Angeles, Calif.); Welsh, M.J.; Zabner, J. (Iowa City, Iowa); Paine, M.L. (Los Angeles, Calif.)

255 Activation of the ERK1/2 Mitogen-Activated Protein Kinase Cascade by Dentin Matrix Protein 1 Promotes Osteoblast Differentiation

Eapen, A.; Ramachandran, A.; Pratap, J.; George, A. (Chicago, Ill.)

261 Phenotypic Variation of Fluoride Responses between Inbred Strains of Mice

Yan, D. (Chapel Hill, N.C.); Willett, T.L. (Toronto, Ont.); Gu, X.-M. (Chapel Hill, N.C.); Martinez-Mier, E.A. (Indianapolis, Ind.); Sardone, L.; McShane, L.; Grynpas, M. (Toronto, Ont.); Everett, E.T. (Chapel Hill, N.C.)

268 Ectopic Expression of Col2.3 and Col3.6 Promoters in the Brain and Association with Leptin Signaling Scheller, E.L.; Leinninger, G.M. (Ann Arbor, Mich.); Hankenson, K.D. (Philadelphia, Pa.); Myers, M.G., Jr. Krebsbach, P.H. (Ann Arbor, Mich.)

274 Bone Cell Autophagy Is Regulated by Environmental Factors Zahm, A.M.; Bohensky, J.; Adams, C.S.; Shapiro, I.M.; Srinivas, V. (Philadelphia, Pa.)

279 Amelogenesis Imperfecta: Genotype-Phenotype Studies in 71 Families

Wright, J.T.; Torain, M.; Long, K. (Chapel Hill, N.C.); Seow, K. (Brisbane, Qld.); Crawford, P. (Bristol); Aldred, M.J. (Melbourne, Vic.); Hart, P.S. (Bethesda, Md.); Hart, T.C. (Chicago, Ill.)

284 Folding, Assembly, and Aggregation of Recombinant Murine Amelogenins with T21I and P41T Point Mutations Bromley, K.M. (Los Angeles, Calif.); Lakshminarayanan, R. (Los Angeles, Calif./Singapore); Lei, Y.-P.; Snead, M.L.; Moradian-Oldak, J. (Los Angeles, Calif.)

291 In vitro Analyses of the Dysregulated R206H ALK2 Kinase-FKBP12 Interaction Associated with Heterotopic Ossification in FOP

Groppe, J.C.; Wu, J. (Dallas, Tex.); Shore, E.M.; Kaplan, F.S. (Philadelphia, Pa.)

296 Differential Enamel and Osteogenic Gene Expression Profiles in Odontogenic Tumors

Ren, C. (Birmingham, Ala.); Diniz, M.G. (Belo Horizonte); Piazza, C.; Amm, H.M.; Rollins, D.L. (Birmingham, Ala.); Rivera, H. (Caracas); Devilliers, P. (Birmingham, Ala.); Kestler, D.P. (Knoxville, Tenn.); Waite, P.D Mamaeva, O.A.; MacDougall, M. (Birmingham, Ala.)

302 Fourier Transform Infrared Imaging Analysis of Cancellous Bone in Alendronate- and Raloxifene-Treated Osteopenic Sheep

Calton, E.F. (New York, N.Y.); MacLeay, J. (Topeka, Kans.); Boskey, A.L. (New York, N.Y.) 
307 Characterization of Oxidative Stress Status during Diabetic Bone Healing

Waddington, R.J.; Alraies, A.; Colombo, J.S.; Sloan, A.J. (Cardiff); Okazaki, J. (Osaka); Moseley, R. (Cardiff)

313 Osteopontin and Wound Healing in Bone

McKee, M.D.; Pedraza, C.E.; Kaartinen, M.T. (Montreal, Que.)

320 The Nature and Role of Periosteum in Bone and Cartilage Regeneration

Matsushima, S. (Rootstown, Ohio/Akron, Ohio/Osaka-sayama); Isogai, N. (Rootstown, Ohio/Osaka-sayama); Jacquet, R.; Lowder, E. (Rootstown, Ohio/ Akron, Ohio); Tokui, T. (Rootstown, Ohio/Osaka-sayama); Landis, W.J. (Rootstown, Ohio/Akron, Ohio)

326 Phenotypic and Differentiation Stability of Human Embryonic Stem Cell-Derived Osteoblasts

Arpornmaeklong, P. (Hat Yai/Ann Arbor, Mich.); Pressler, M.J.; Krebsbach, P.H. (Ann Arbor, Mich.)

331 Other Presenters

340 Participant Contact List

346 Author Index

347 Subject Index

\section{No. 5}

Original Papers

349 Pitx2c Modulates Cardiac-Specific Transcription Factors Networks in Differentiating Cardiomyocytes from Murine Embryonic Stem Cells

Lozano-Velasco, E.; Chinchilla, A.; Martínez-Fernández, S.; Hernández-Torres, F.; Navarro, F. (Jaén); Lyons, G.E. (Madison, Wisc.); Franco, D.; Aránega, A.E. (Jaén)

363 Possible Role of NF-kB Signals in Heat Stress-Associated Increase in Protein Content of Cultured C2C12 Cells Ohno, Y. (Toyohashi/Nagoya); Yamada, S. (Nagoya); Sugiura, T. (Yamaguchi); Ohira, Y. (Toyonaka); Yoshioka, T. (Hirosaki); Goto, K. (Toyohashi)

371 Acute Hepatic Failure-Derived Bone Marrow Mesenchymal Stem Cells Express Hepatic Progenitor Cell Genes Li, J.; Wu, W.; Xin, J.; Guo, J.; Jiang, L.; Tao, R.; Cao, H.; Hong, X.; Li, L. (Hangzhou)

382 The Progressive Ankylosis Protein Regulates Cementum Apposition and Extracellular Matrix Composition Foster, B.L.; Nagatomo, K.J.; Bamashmous, S.O. (Seattle, Wash.); Tompkins, K.A. (Seattle, Wash./Bangkok); Fong, H.; Dunn, D.; Chu, E.Y. (Seattle, Wash.); Guenther, C.; Kingsley, D.M. (Stanford, Calif.); Rutherford, R.B.; Somerman, M.J. (Seattle, Wash.)

406 Occurrence of Cleft-Palate and Alteration of Tgf- $\beta_{3}$ Expression and the Mechanisms Leading to Palatal Fusion in Mice following Dietary Folic-Acid Deficiency Maldonado, E.; Murillo, J.; Barrio, C.; del Río, A.; Pérez-Miguelsanz, J.; López-Gordillo, Y. (Madrid); Partearroyo, T. (Boadilla del Monte); Paradas, I.; Maestro, C.; Martínez-Sanz, E. (Madrid); Varela-Moreiras, G. (Boadilla del Monte); Martínez-Álvarez, C. (Madrid)

421 Immunosuppressant Prograf ${ }^{\circledR}$ (Tacrolimus) Induces Histopathological Disorders in the Peritubular Tissue of Rat Testes

Caneguim, B.H. (São Paulo); Cerri, P.S.; Spolidório, L.C. (Araraquara); Miraglia, S.M. (São Paulo); Sasso-Cerri, E. (Araraquara)

431 Relating Function to Branching Geometry: A Micro-CT Study of the Hepatic Artery, Portal Vein, and Biliary Tree Kline, T.L. (Rochester, Minn.); Zamir, M. (London, Ont.); Ritman, E.L. (Rochester, Minn.)
No. 6

Original Papers

443 Retinal Pigment Epithelium Cell Alignment on Nanostructured Collagen Matrices

Ulbrich, S. (Dresden); Friedrichs, J. (Dresden/Basel); Valtink, M. (Dresden); Murovski, S. (Dresden/Chemnitz); Franz, C.M. (Dresden/Karlsruhe); Müller, D.J. (Dresden/Basel); Funk, R.H.W. (Dresden); Engelmann, K. (Dresden/Chemnitz)

457 Establishment and Characterization of Porcine Colonic Epithelial Cells Grown in Primary Culture

Petto, C.; Lesko, S.; Gäbel, G. (Leipzig); Böttner, M.; Wedel, T. (Kiel); Kacza, J.; Pfannkuche, H. (Leipzig)

469 Human Galectins Induce Conversion of Dermal Fibroblasts into Myofibroblasts and Production of Extracellular Matrix: Potential Application in Tissue Engineering and Wound Repair Dvořánková, B.; Szabo, P.; Lacina, L. (Prague); Gal, P. (Prague/Košice); Uhrova, J.; Zima, T. (Prague); Kaltner, H.; André, S.; Gabius, H.-J. (Munich); Sykova, E.; Smetana, K., Jr., (Prague)

481 Maxillary Sinus Floor Elevation Using a Tissue-Engineered Bone with rhBMP-2-Loaded Porous Calcium Phosphate Cement Scaffold and Bone Marrow Stromal Cells in Rabbits Xia, L.; Xu, Y.; Wei, J.; Zeng, D.; Ye, D.; Liu, C.; Zhang, Z.; Jiang, X. (Shanghai)

494 The Effect of Storage Time on Adipose-Derived Stem Cell Recovery from Human Lipoaspirates

Carvalho, P.P. (Baton Rouge, La./Guimarães/Braga); Wu, X.; Yu, G. (Baton Rouge, La.); Dias, I.R. (Guimarães/Braga/Vila Real); Gomes, M.E.; Reis, R.L. (Guimarães/Braga); Gimble, J.M. (Baton Rouge, La.)

501 Evaluation of Functional and Structural Alterations in Muscle Tissue after Short-Term Cold Storage in a New Tissue Preservation Solution

Wille, T.; Gonder, S.; Thiermann, H.; Seeger, T. (Munich); Rauen, U. (Essen); Worek, F. (Munich)

510 Matrix Metalloproteinase-9 Deficiency Results in Decreased Fiber Cross-Sectional Area and Alters Fiber Type Distribution in Mouse Hindlimb Skeletal Muscle

Mehan, R.S.; Greybeck, B.J; Emmons, K.; Byrnes, W.C.; Allen, D.L. (Boulder, Colo.)

521 Sensory Innervation of the Nonspecialized Connective Tissues in the Low Back of the Rat

Corey, S.M.; Vizzard, M.A.; Badger, G.J.; Langevin, H.M. (Burlington, Vt.)

531 Acknowledgement to Referees

533 Author Index Vol. 194, 2011 